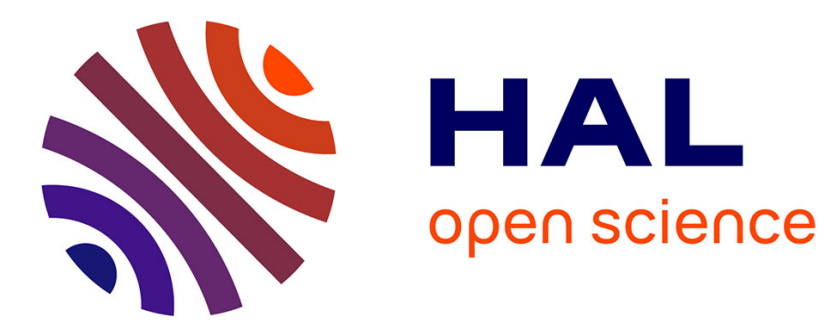

\title{
A protocol for ethanol or isopropanol dosage in hand rub gels
}

Ayman Akhdar, Yael Hersant, Arnaud Gautier

\section{To cite this version:}

Ayman Akhdar, Yael Hersant, Arnaud Gautier. A protocol for ethanol or isopropanol dosage in hand rub gels. 2020. hal-02995153

\section{HAL Id: hal-02995153 \\ https://hal.science/hal-02995153}

Preprint submitted on 2 Dec 2020

HAL is a multi-disciplinary open access archive for the deposit and dissemination of scientific research documents, whether they are published or not. The documents may come from teaching and research institutions in France or abroad, or from public or private research centers.
L'archive ouverte pluridisciplinaire HAL, est destinée au dépôt et à la diffusion de documents scientifiques de niveau recherche, publiés ou non, émanant des établissements d'enseignement et de recherche français ou étrangers, des laboratoires publics ou privés. 


\title{
28 Research Suare \\ A protocol for ethanol or isopropanol dosage in hand rub gels
}

\author{
Ayman Akhdar \\ UCA \\ Yael Hersant \\ CNRS \\ Arnaud Gautier ( $\square$ arnaud.gautier@uca.fr ) \\ CNRS
}

\section{Method Article}

Keywords: quantitative $1 \mathrm{H}$ RMN, hand rub solutions, analytical chemistry

DOI: https://doi.org/10.21203/rs.3.pex-1205/v1

License: (c) (i) This work is licensed under a Creative Commons Attribution 4.0 International License.

Read Full License 


\section{Abstract}

A method of determination of the ethanol or isopropanol content in hydro-alcoholics hand rub solutions is reported. Based on quantitative ${ }^{1} \mathrm{HNMR}$ ( $\mathrm{q}^{1} \mathrm{HNMR}$ ), the results are obtained rapidly and accurately. The method is available for viscous solutions to which other simpler techniques do not apply.

\section{Introduction}

As the spread of the COVID-19 pandemic accelerates around the world, many low- and middle-income countries are still struggling to access the diagnostic tests they desperately need to control the disease. Moreover, passive protection methods such as masks and hydro-alcoholic gels are the first means of defence to avoid chaotic spread of the virus among the population. The World Health Organization (WHO) provides a protocol that was taken into consideration in many national legislations. ${ }^{1}$ In France, at the beginning of the pandemic, we applied this protocol to fabricate several dozens of litres of hydroalcoholic mixture at our institute and the contents of ethanol or isopropanol in grams per grams of solution was determined by ${ }^{1} \mathrm{H}$ quantitative NMR (qNMR). If the contents of alcohols in liquids gels can be approximatively measured using a simple alcohol-meter, this technic is less appropriate for viscous liquids containing gelling agents. We report here a method of ethanol content measurement using ${ }^{1} \mathrm{H}$ quantitative NMR ( ${ }^{1} \mathrm{H}$ qNMR). Our intention is to remind the scientific community of this well-known technic.

\section{Reagents}

D2O

3-(trimethylsilyl)-1-propanesulfonic acid di sodium salt (TSPA, CAS: 2039-96-5, 97\% purity).

\section{Equipment}

NMR Brucker 400MHz.

3mm NMR tubes (Norell).

Balance (0.01 mg accuracy).

$4 \mathrm{~mL}$ flat bottom screw neck vial equipped with a centred hole, screw closure closed by a silicone PTFE syringe (Inject®-F $1 \mathrm{ml})$

needle (Henke Sass Wolf, Germany, 0.6X25mm)

\section{Procedure}




\section{Sample preparation:}

- Masses are weighed using a Mettler Toledo balance (0.01 $\mathrm{mg}$ accuracy) into a $4 \mathrm{~mL}$ flat bottom screw neck vial equipped with a centred hole closed by a silicone PTFE (Macherey-Nagel, Germany).

- The standard is weighted first, then $2 \mathrm{~mL}$ of $\mathrm{D}_{2} \mathrm{O}$ are introduced.

- The vial is then closed and gently shaken until all the solid dissolves.

- The gel is added into the vial with a syringe (Inject@- $\mathrm{F} 1 \mathrm{ml}$ ) equipped with a needle (Henke Sass Wolf, Germany, $0.6 \times 25 \mathrm{~mm}$ ) through the silicone join in order to minimize the evaporation of ethanol. - The solution was shaken, then $600 \mathrm{~mL}$ were transferred into $3 \mathrm{~mm}$ standard NMR tubes (Norell) for analysis.

\section{Pulse Program.}

Single pulse, without carbon decoupling ('zg' with 90 pulse). Data Points (acquired): $64 \mathrm{~K}$. NS=64. Relaxation delay: D1=60s. Acquisition Time: $4 \mathrm{~s}$. Spectral window for proton: SW=30ppm and 01: 7.5 ppm (the sample Temperature is fixed at $19{ }^{\circ} \mathrm{C} \pm 0.1 \mathrm{~K}$ ).

\section{Post-Acquisition Processing.}

Performed with ACDLABS software (1.2, academic version). Zero Filling: to 256K. Line Broadening: LB = $0.1 \mathrm{~Hz}$. Phasing: manually. Baseline Correction: 6th order polynomial (for each signal measured a ratio signal/noise $>100$ is verified).

\section{Troubleshooting}

It is important to use a screw neck vial closed by a silicone PTFE and an appropriate syringe and needle to minimize ethanol evaporation during the sample preparation.

\section{Time Taken}

Sample preparation: 10 minutes

NMR acquisition: $1 \mathrm{~h}$

NMR processing: 10 minutes

\section{Anticipated Results}

Quantitative NMR is a valuable method because the measured signals represent a direct measurement of the composition if correct inter-pulse delay are adequately chosen. ${ }^{2}$ Therefore, in presence of an internal 
reference of known purity, the composition of a sample can be determined accurately using a single spectrum/ integration sequence (so-called absolute quantification). For this purpose, we used 3(trimethylsilyl)-1-propanesulfonic acid di sodium salt (TSPA, CAS: 2039-96-5, 97\% purity) as standard (also used as chemical shift reference) and $\mathrm{D}_{2} \mathrm{O}$ for NMR solvent.

After proper weighting of the standard and the gel, the masses of ethanol or isopropanol contained in the samples are calculated by equations 1 :

$$
\begin{aligned}
& \text { Masse }=\left[15 \times 0.97 \times \mathrm{M}^{(\text {Alc })} \times \operatorname{SInt}^{\text {Alc }} \times \mathrm{m}^{(\mathrm{Std})}\right] /\left[218.3 \mathrm{Xn}^{1} \mathrm{H}^{(\mathrm{Alc})} \times \mathrm{SInt}^{(\mathrm{Std})}\right] \\
& =\left[0.06665 \times \mathrm{M}^{(\mathrm{Alc})} \times \mathrm{SInt}^{\mathrm{Alc}} \times \mathrm{X} \mathrm{m}^{(\mathrm{Std})}\right] /\left[\mathrm{n}^{1} \mathrm{H}^{(\mathrm{Alc})} \times \operatorname{SInt}^{(\mathrm{Std})}\right] \mathrm{Eq} .1
\end{aligned}
$$

Where $\mathrm{M}^{(\mathrm{Alc})}, \mathrm{n}^{1} \mathrm{H}^{(\mathrm{Alc})}$ and $\mathrm{m}^{(\mathrm{Std})}$ are respectively the molecular mass, the number of integrated proton and the weighted masse of the chosen alcohol; SInt ${ }^{(\mathrm{Alc})}$ and SInt ${ }^{(\mathrm{Std})}$ being the sum of the integrals for the chosen alcohol and the standard; 15 and 218 and 0.97 being the total number of proton, the molecular mass and the purity of the standard.

For ethanol and isopropanol respectively, the equation resumes to:

Mass $^{(\text {ethanol })}=\left[0.615 \times \operatorname{SInt}^{(\mathrm{Alc})} \times \mathrm{m}^{(\mathrm{Std})}\right] / \operatorname{SInt}^{(\mathrm{Std})} \mathrm{Eq} .2$

Mass $^{(\text {isopropanol) })}=\left[0.572 \times \operatorname{SInt}^{(\text {Alc })} \times \mathrm{m}^{(\mathrm{Std})}\right] / \mathrm{SInt}^{(\mathrm{Std})} \mathrm{Eq} .3$

We found $75 \%$ and $68 \%$ for handrub solutions produced according to the WHO protocols. The weighted masses were TSPA, $18.14 \mathrm{mg}$, ethanolic gel: $34.69 \mathrm{mg}$ (Figure 1) and TSPA: $41.85 \mathrm{mg}$, isopropanol gel: 25.95mg (Figure 2).

\section{References}

1. https://www.who.int/gpsc/5may/Guide_to_Local_Production.pdf?ua=1

2. Pauli, G.F.; Chen, S.N.; Simmler, C.; Lankin, D.C.; Gödecke, T.; Jaki, B.U.; Friesen, J.B.; McAlpine, J.B.; Napolitano, J.G. Importance of purity evaluation and the potential of quantitative ${ }^{1} \mathrm{H}$ NMR as a purity assay. J Med Chem., 57, 9220-31 (2014). 